\title{
Bariatric surgery in individuals with human immunodeficiency virus and type 2 diabetes: a case series
}

\author{
Wei Yang ${ }^{1,7^{*}}$, Anjali Zalin², Mark Nelson ${ }^{3}$, Gianluca Bonanomi ${ }^{4}$, James Smellie ${ }^{5}$, Kevin Shotliff ${ }^{6}$ \\ Evangelos Efthimiou ${ }^{4}$ and Veronica Greener ${ }^{1}$
}

\begin{abstract}
Background: The efficacy and safety of bariatric surgery have not been fully elucidated in patients affected with human immunodeficiency virus. Although adjustable gastric banding and sleeve gastrectomy are starting to be used in patients with human immunodeficiency virus, there are limited descriptions of the outcomes of type 2 diabetes mellitus in individuals who are human immunodeficiency virus positive and undergoing these procedures.

Case presentation: We have evaluated retrospectively three patients who underwent adjustable gastric banding or sleeve gastrectomy, the effect in weight reduction and glycemic control as well as its impact on human immunodeficiency virus management. Case 1 (adjustable gastric banding), a 58-year-old Caucasian male, achieved 19\% total weight loss, Case 2, a 33-year-old Caucasian male (sleeve gastrectomy) lost 25\%, and Case 3, a 48-year-old Caucasian female (sleeve gastrectomy), lost 14\% postoperation. In terms of type 2 diabetes mellitus, Case 2 achieved complete remission according to American Diabetes Association criteria, while Case 1 would also have achieved remission were it not for the continuation of metformin postoperatively. Insulin requirements and pill burden were markedly reduced in Case 3 after sleeve gastrectomy, although lack of remission was predictable given the longevity of type 2 diabetes mellitus and preoperative insulin dosage. In all three cases, human immunodeficiency virus status did not appear to be affected by the bariatric surgery which was supported by the postoperative stable CD4 count and undetectable viral load.
\end{abstract}

Conclusions: Bariatric surgery is a safe and effective treatment modality in patients who are human immunodeficiency virus positive with obesity and type 2 diabetes mellitus.

Keywords: Bariatric surgery, Type 2 diabetes, Human immunodeficiency virus

\section{Background}

Obesity, type 2 diabetes mellitus (T2DM), and human immunodeficiency virus (HIV) are prominent global health issues. With the advent of highly active antiretroviral treatment (HAART) and improved mortality rates, people with HIV infection increasingly present with obesity and related metabolic consequences [1]. Bariatric procedures, including adjustable gastric banding (AGB), sleeve gastrectomy (SG), and Roux-en-Y gastric bypass

\footnotetext{
* Correspondence: yangweifall@gmail.com

'Bariatric Medicine, Chelsea and Westminster Hospital, 369 Fulham Road, Chelsea, London SW10 9NH, UK

${ }^{7}$ Beta Cell Diabetes Centre, Chelsea and Westminster Hospital, 369 Fulham Road, Chelsea, London SW10 9NH, UK

Full list of author information is available at the end of the article
}

(RYGB), are effective therapies for morbid obesity with high rates of T2DM resolution [2]. Until recently, however, bariatric surgery in the HIV-positive population remained controversial [3].

The first report of a patient with HIV infection undergoing bariatric surgery was in 2005 [4], and, subsequently, a small number of studies, including within our own unit, have reported outcomes [5]. Bariatric surgery is now considered a safe and effective treatment for people with morbid obesity who are also infected with HIV [6]. Notably, to date, there are limited descriptions of T2DM outcomes in such individuals. Given the increasing prevalence of this combination of conditions, we present a case series to advance this discussion.

(c) The Author(s). 2019 Open Access This article is distributed under the terms of the Creative Commons Attribution 4.0 International License (http://creativecommons.org/licenses/by/4.0/), which permits unrestricted use, distribution, and 
Table 1 Preoperative assessment for the bariatric surgery on admission

\begin{tabular}{|c|c|c|c|}
\hline & Case 1 & Case 2 & Case 3 \\
\hline $\begin{array}{l}\text { Past medical } \\
\text { history }\end{array}$ & $\begin{array}{l}\text { Hypertension, dyslipidemia, T2DM, obstructive } \\
\text { sleep apnea, obesity, gout, Burkitt's lymphoma, } \\
\text { HIV, CKD stage 2, hydrocele repair, } \\
\text { tonsillectomy }\end{array}$ & $\begin{array}{l}\text { Obesity, T2DM, obstructive } \\
\text { sleep apnea, depression, HIV, } \\
\text { fatty liver disease, } \\
\text { tonsillectomy }\end{array}$ & $\begin{array}{l}\text { Obesity, T2DM, asthma, dyslipidemia, obstructive } \\
\text { sleep apnea, urinary incontinence, peripheral } \\
\text { neuropathy, knee osteoarthritis, depression, } \\
\text { vitamin D deficiency. }\end{array}$ \\
\hline Drug history & $\begin{array}{l}\text { Allergic to co-trimoxazole. } \\
\text { Metformin } 500 \mathrm{mg} \text { twice a day } \\
\text { Losartan } 100 \mathrm{mg} \text { once a day } \\
\text { Allopurinol } 200 \mathrm{mg} \text { once a day } \\
\text { Atorvastatin } 10 \mathrm{mg} \text { once a day } \\
\text { Indapamide } 1.5 \mathrm{mg} \text { once a day }\end{array}$ & $\begin{array}{l}\text { No known drug allergy. } \\
\text { Mirtazapine } 30 \mathrm{mg} \text { once a } \\
\text { day } \\
\text { Metformin } 500 \mathrm{mg} \text { once a day }\end{array}$ & $\begin{array}{l}\text { No known drug allergy. } \\
\text { Ranitidine } 300 \mathrm{mg} \text { once a day } \\
\text { Atorvastatin } 10 \mathrm{mg} \text { once a day } \\
\text { Metformin } 1 \mathrm{~g} \text { three times a day } \\
\text { Dapagliflozin } 10 \mathrm{mg} \text { once a day } \\
\text { Exenatide } 20 \mathrm{mcg} \text { once a day } \\
\text { Detemir } 70 \text { units twice a day }\end{array}$ \\
\hline $\begin{array}{l}\text { HIV } \\
\text { medications }\end{array}$ & $\begin{array}{l}\text { Atripla (efavirenz/emtricitabine/tenofovir) } 1 \\
\text { tablet once a day }\end{array}$ & $\begin{array}{l}\text { Atripla (efavirenz/ } \\
\text { emtricitabine/tenofovir) } 1 \\
\text { tablet once a day }\end{array}$ & $\begin{array}{l}\text { Truvada (emtricitabine/tenofovir) 245/200 mg } \\
\text { once a day } \\
\text { Darunavir } 800 \mathrm{mg} \text { once a day } \\
\text { Ritonavir } 100 \mathrm{mg} \text { once a day }\end{array}$ \\
\hline Family history & $\begin{array}{l}\text { Father - aortic aneurysm } \\
\text { Mother - Alzheimer's }\end{array}$ & Nil & Nil \\
\hline \multicolumn{4}{|l|}{ Social history } \\
\hline $\begin{array}{l}\text { Tobacco } \\
\text { smoking }\end{array}$ & $\mathrm{Nil}$ & Occasional & Nil \\
\hline Alcohol & 40 units/month & Occasional & Nil \\
\hline Employment & Computer programmer & Unemployed & Unemployed \\
\hline Independence & $\begin{array}{l}\text { Lives with family, independent of daily } \\
\text { activities }\end{array}$ & $\begin{array}{l}\text { Lives with friends, } \\
\text { independent of daily activities }\end{array}$ & $\begin{array}{l}\text { Lives with daughter, wheelchair bound most of } \\
\text { the time }\end{array}$ \\
\hline \multirow[t]{5}{*}{ Observations } & $H R-70$ & $H R-100$ & $H R-83$ \\
\hline & $R R-16$ & $R R-16$ & $\mathrm{RR}-18$ \\
\hline & Sats - 99\% & Sats - 95\% & Sats - 95\% \\
\hline & $B P-128 / 72$ & $B P-136 / 90$ & $B P-145 / 83$ \\
\hline & $\mathrm{T}-36.4^{\circ} \mathrm{C}$ & $\mathrm{T}-36.1^{\circ} \mathrm{C}$ & $\mathrm{T}-36.7^{\circ} \mathrm{C}$ \\
\hline $\begin{array}{l}\text { Physical } \\
\text { examinations }\end{array}$ & Mild right knee joint pain & $\begin{array}{l}\text { Mild bilateral joint pain and } \\
\text { low back pain. } \\
\text { Fungal infection right axilla }\end{array}$ & Mild bilateral joint pain and low back pain. \\
\hline $\begin{array}{l}\text { Neurology } \\
\text { examinations }\end{array}$ & NAD & NAD & $\begin{array}{l}\text { Numbness below the knee bilaterally. } \\
\text { Urinary incontinence }\end{array}$ \\
\hline
\end{tabular}

$B P$ blood pressure, $C K D$ chronic kidney disease, HIV human immunodeficiency virus, $H R$ heart rate, NAD no abnormality detected, $R R$ respiration rate, Sats oxygen saturation, $T$ temperature, $T 2 D M$ type 2 diabetes mellitus

\section{Cases presentation}

\section{Methods of case collection}

We studied 120 patients with T2DM who underwent bariatric surgery between 2010 and 2017 at Chelsea and Westminster Hospital, London. The patients groups were: AGB $(n=62)$ and SG $(n=58)$. Three patients known to be HIV antibody positive form the basis of this series. Selection for bariatric surgery was consistent with National Institute for Health and Care Excellence (NICE) guidelines with procedural type co-decided by the patient and the multidisciplinary team (MDT). Procedural descriptions are provided elsewhere [7]. Utilizing hospital pathology and electronic record systems, information was collected on: demographics; anthropometrics; weight history; surgical details; perioperative diabetes status; perioperative HIV status, and major outcomes.

\section{Case 1}

Case 1 is a 58-year-old Caucasian male with a history of HIV infection (2002), T2DM (2008), and obesity. His comorbidities included hypertension, dyslipidemia, and obstructive sleep apnea. (Table 1). Preoperatively, he was prescribed metformin $500 \mathrm{mg}$ twice a day and glycated hemoglobin (HbA1c) was $40 \mathrm{mmol} / \mathrm{mol}$. His baseline body mass index (BMI) was $47 \mathrm{~kg} / \mathrm{m}^{2}$, with a weight of $162.9 \mathrm{~kg}$. Multiple attempts at weight loss, including commercial diets and orlistat, had been unsuccessful. HIV prescriptions included one tablet daily of Atripla (efavirenz/emtricitabine/tenofovir). His preoperative CD4 count was 800 cells $/ \mu \mathrm{L}$ and viral load was undetectable. Following assessment by the bariatric MDT, he was found to meet criteria for surgery.

In 2012 he underwent laparoscopic AGB surgery and had an uncomplicated postoperative course. Preoperative 
Table 2 Preoperative and final postoperative clinical parameters for Cases 1-3

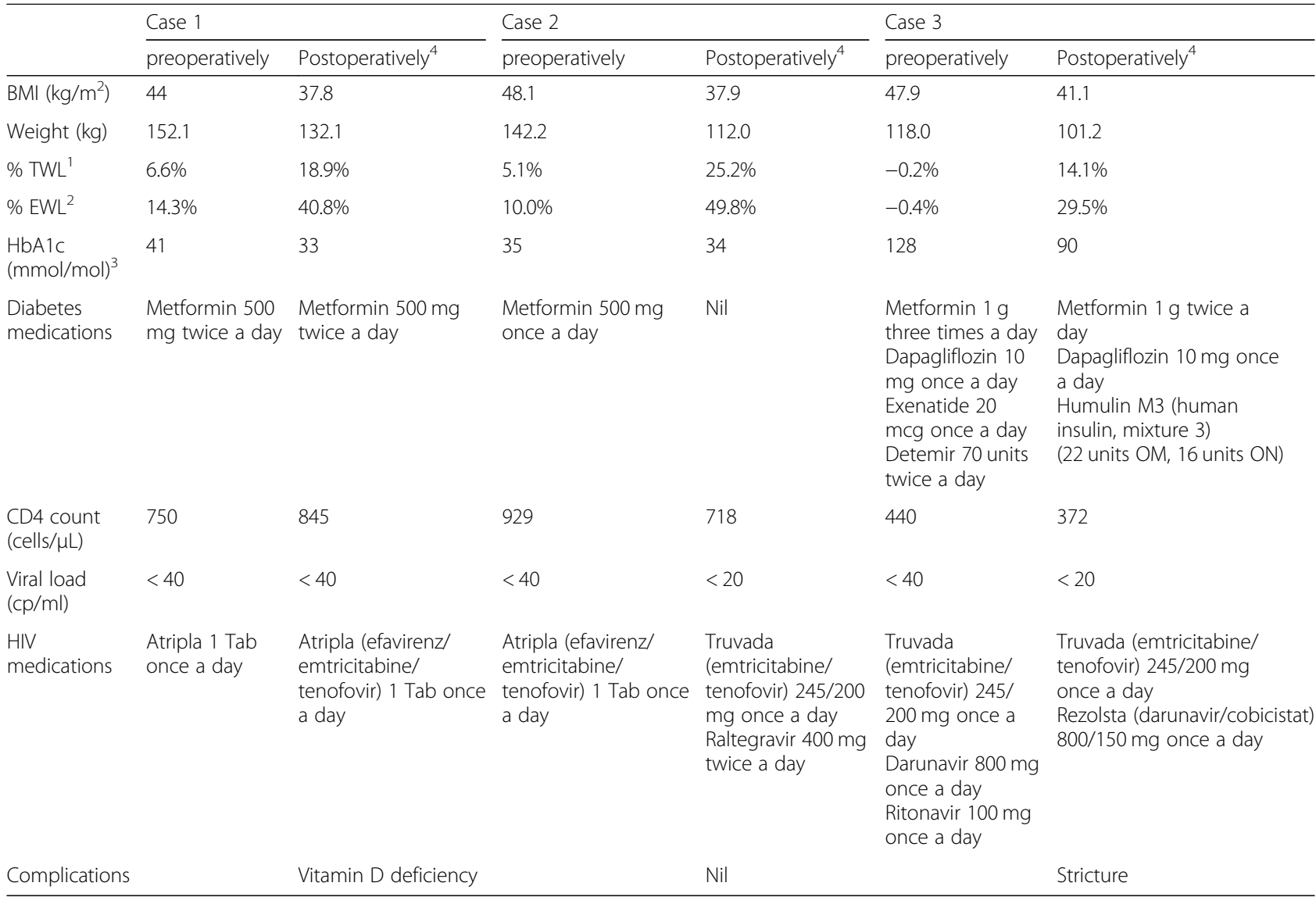

BMI body mass index, EWL excessive weight loss, HbA1c glycated hemoglobin, HIV human immunodeficiency virus, Tab tablet, $T W L$ total weight loss, OM in the morning, ON at night. ${ }^{1} \% T W L$ : percentage of total weight loss, ${ }^{2} \% E W L$ : percentage of excess weight loss, calculated by dividing weight changes from baseline by excess body weight. The latter value was obtained by subtracting the ideal body weight as that equivalent to a body mass index of $25 \mathrm{~kg} / \mathrm{m} 2 \mathrm{from}$ the actual baseline weight, ${ }^{3}$ normal range of glycated haemoglobin is $20-41 \mathrm{mmol} / \mathrm{mol},{ }^{4}$ last follow-up ( $>3$ years in all cases)

and postoperative clinical parameters are presented in Tables 1,2 , and 3 and Fig. 1 with sustained weight loss reported. As per local guidelines, this patient continued to receive metformin $500 \mathrm{mg}$ twice a day postoperatively to optimize insulin sensitivity. Six months postoperatively, $\mathrm{HbA} 1 \mathrm{c}$ was $35 \mathrm{mmol} / \mathrm{mol}$, and there was no evidence of diabetes-related complications. His HIV infection status was not affected by surgery, and he continued to receive Atripla (efavirenz/emtricitabine/tenofovir). His CD4 count was unchanged at each postoperative visit, with undetectable viral load throughout. He continues to be on antiretroviral and antidiabetic medications as well (metformin $500 \mathrm{mg}$ twice a day) and reports sustained weight loss.

\section{Case 2}

Case 2 is a 33-year-old Caucasian male who was positive for HIV (2011) with a background of T2DM, obesity, depression, and fatty liver disease (Table 1). His baseline BMI was $50.7 \mathrm{~kg} / \mathrm{m}^{2}$ with a weight of $149.8 \mathrm{~kg}$. Following 2 years of orlistat therapy and lifestyle intervention, his
BMI decreased modestly to $48.1 \mathrm{~kg} / \mathrm{m}^{2}$. Preoperatively, T2DM was controlled with metformin $500 \mathrm{mg}$ once a day and his $\mathrm{HbA} 1 \mathrm{c}$ was $35 \mathrm{mmol} / \mathrm{mol}$. Following 2 years of HAART for which he received Atripla (efavirenz/ emtricitabine/tenofovir) 1 tablet once a day, his CD4 count increased to 929 cells $/ \mu \mathrm{L}$ from 552 cells $/ \mu \mathrm{L}$ at diagnosis. Viral load was undetectable. Further preoperative and postoperative parameters are presented in Tables 1, 2, and 3 and Fig. 1.

A laparoscopic SG was performed in 2013. He reported no complications at postoperative follow-up. T2DM was diet controlled following surgery and his HbA1c remained stable $(33 \mathrm{mmol} / \mathrm{mol} \mathrm{mean})$. Therefore, complete diabetes remission was achieved according to American Diabetes Association (ADA) criteria [8]. Postoperatively, his viral load remained undetectable with a mean CD4 count of 735 cells/ $\mu \mathrm{L}$. Following clinical trial recruitment, antiretroviral medication was adjusted in an attempt to better stabilize mood. Depressive symptoms improved and HIV status remained stable. 
Table 3 Results of routine laboratory tests pre-bariatric operation and post-bariatric operation

\begin{tabular}{|c|c|c|c|c|c|c|}
\hline & \multicolumn{2}{|l|}{ Case 1} & \multicolumn{2}{|l|}{ Case 2} & \multicolumn{2}{|l|}{ Case 3} \\
\hline & Preoperation* & Postoperation^ & Preoperation* & Postoperation^^ & Preoperation* & Postoperation^ $\wedge$ \\
\hline \multicolumn{7}{|l|}{ FBC } \\
\hline $\mathrm{Hb}(\mathrm{g} / \mathrm{L})$ & 129 & 156 & 143 & 165 & 122 & 119 \\
\hline WCC $\left(\times 10^{9} / \mathrm{L}\right)$ & 4.9 & 5.9 & 8.1 & 7.3 & 4.3 & 3.2 \\
\hline $\operatorname{PLT}\left(\times 10^{9} / \mathrm{L}\right)$ & 149 & 204 & 186 & 243 & 270 & 182 \\
\hline CRP (mg/L) & 28 & 5 & 1 & 12 & 22 & 1 \\
\hline \multicolumn{7}{|l|}{ U\&Es } \\
\hline $\mathrm{Na}(\mathrm{mmol} / \mathrm{L})$ & 138 & 142 & 138 & 139 & 137 & 144 \\
\hline $\mathrm{K}(\mathrm{mmol} / \mathrm{L})$ & 3.8 & 3.6 & 4.3 & 4.6 & 4.1 & 4.3 \\
\hline Urea (mmol/L) & 4.6 & 6.5 & 2.2 & 5.4 & 4.0 & 7.2 \\
\hline $\mathrm{Cr}(\mathrm{mmol} / \mathrm{L})$ & 94 & 139 & 67 & 54 & 80 & 65 \\
\hline eGFR (ml/minute/1.73m²) & 73 & 47 & $>90$ & $>90$ & 67 & $>90$ \\
\hline \multicolumn{7}{|l|}{ LFTs } \\
\hline Bili $(\mu \mathrm{mol} / \mathrm{l})$ & 10 & 6 & 9 & 9 & 6 & 4 \\
\hline ALP (IU/L) & 30 & 34 & 45 & 30 & 10 & 19 \\
\hline ALT (IU/L) & 59 & 65 & 80 & 95 & 109 & 66 \\
\hline $\mathrm{ALB}(\mathrm{g} / \mathrm{L})$ & 36 & 40 & 35 & 41 & 28 & 33 \\
\hline \multicolumn{7}{|l|}{ Urine analysis } \\
\hline Specific gravity & 1.030 & 1.030 & 1.015 & 1.020 & 1.030 & 1.010 \\
\hline $\mathrm{pH}$ & 5.5 & 5.0 & 6.0 & 5.5 & 5.5 & 6.0 \\
\hline Protein (mg/L) & Negative & + & Negative & Negative & + & + \\
\hline Glucose (mmol/L) & Negative & Negative & Negative & Negative & + & + \\
\hline Urine culture & Negative & Negative & Negative & Negative & Negative & Negative \\
\hline Fecal culture & N/A & N/A & N/A & N/A & $\mathrm{N} / \mathrm{A}$ & N/A \\
\hline Blood culture & N/A & N/A & N/A & N/A & N/A & N/A \\
\hline
\end{tabular}

$A L B$ albumin, $A L P$ alkaline phosphatase, $A L T$ alanine aminotransferase, Bili bilirubin, $C r$ creatinine, $C R P$ C-reactive protein, eGFR estimated glomerular filtration rate, $F B C$ full blood count, $H b$ hemoglobin, $K$ potassium, LFTs liver function tests, Na sodium, N/A not applicable, PLT platelet, U\&Es urea and electrolytes, WCC white cell count

*on admission to receive bariatric surgery, $\wedge$ last follow-up ( $>3$ years postoperation for all cases)

\section{Case 3}

Case 3 is a 48-year-old Caucasian female with a history of obesity, HIV disease (2003), and poorly controlled T2DM with peripheral neuropathy (2003) (Table 1). Her baseline BMI was $47.8 \mathrm{~kg} / \mathrm{m}^{2}$ and multiple attempts at weight loss had been unsuccessful. Her preoperative HIV status was well controlled (CD4 count 440 cells/ $\mu \mathrm{L}$, undetectable viral load) with Truvada (emtricitabine/ tenofovir), darunavir, and ritonavir. Unfortunately, despite various treatments of sodium-glucose co-transporter-2 (SGLT-2) inhibitor, high-dose insulin sensitizer, glucagon-like peptide-1 (GLP-1) agonist, and high-dose basal insulin, her HbA1c remained elevated at $128 \mathrm{mmol} / \mathrm{mol}$. Extensive discussions were undertaken with the patient and the MDT. Despite lack of glycemic optimization, benefits were deemed to outweigh risks and so SG was scheduled.

Preoperative and postoperative clinical parameters are presented in Tables 1, 2, and 3 and Fig. 1. Her
T2DM status improved following surgery: HbA1c dropped to $90 \mathrm{mmol} / \mathrm{mol} 2$ years postoperatively (accompanying fasting glucose of $12 \mathrm{mmol} / \mathrm{L}$ ). Unsurprisingly, given T2DM duration, preceding control, and preoperative insulin requirements, diabetes remission was not achieved in this case. Following surgery, however, she benefits from a reduced pill burden and markedly reduced daily insulin requirements (38 versus 140 units preoperatively). Anti-retroviral medications were switched to Truvada (emtricitabine/tenofovir) and Rezolsta (darunavir/cobicistat) and her HIV status remained stable (CD4 count 400 cells $/ \mu \mathrm{L}$, undetectable viral load). An esophageal stricture which developed 2 years postoperatively responded to a dilatation procedure. No further complications have occurred.

\section{Discussion}

Here we present three differing cases which add to the literature supporting bariatric surgery as a safe 


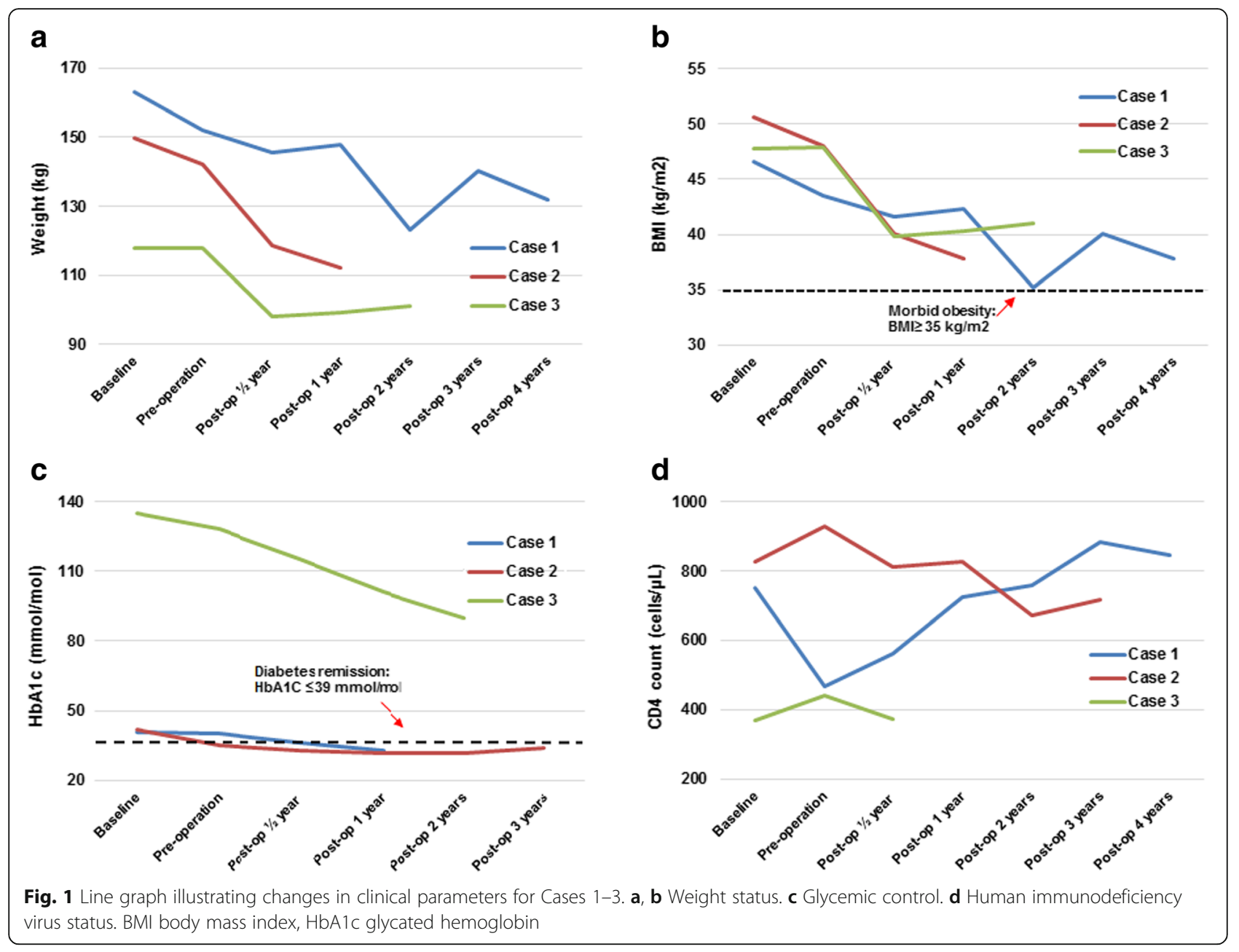

treatment modality in individuals who are HIV positive. Our cases series is novel as we have compared the effects of bariatric surgery on weight reduction and glycemic control in patients with HIV infection as well as patients without HIV infection.

T2DM prevalence and complication rates in the HIV-infected population (23-40\%) are noticeably higher than the general population [9]. Traditional risk factors as well as HIV-specific factors including anti-retrovirals and lipodystrophy syndrome contribute to the pathogenesis [9]. A strong body of evidence supports the use of bariatric surgery as a treatment modality for T2DM in the context of obesity [10] with sustained remission of T2DM described [7]. Also

Table 4 Summary of clinical outcomes in patients who are human immunodeficiency virus positive and patients who are not human immunodeficiency virus positive referred for bariatric surgery

\begin{tabular}{|c|c|c|c|c|c|c|}
\hline & \multirow{2}{*}{$\begin{array}{l}\text { Baseline } \\
\text { BMI }\end{array}$} & \multirow{2}{*}{$\begin{array}{l}\% \text { TWL } \\
\text { postop } \\
\text { after } 2 \\
\text { years }\end{array}$} & \multirow{2}{*}{$\begin{array}{l}\% \text { EWL } \\
\text { postop } \\
\text { after } 2 \\
\text { years }\end{array}$} & \multicolumn{2}{|l|}{$\mathrm{HbA1c}$} & \multirow{2}{*}{$\begin{array}{l}\text { Complete } \\
\text { remission } \\
\text { of } \mathrm{T}^{2} \mathrm{DM}^{1}\end{array}$} \\
\hline & & & & Preop & Postop after 1 year & \\
\hline HIV case 1 (AGB) & 46.6 & $24.4 \%$ & $52.6 \%$ & 41 & 33 & No \\
\hline HIV case 2 (SG) & 50.7 & $25.2 \%$ & $49.8 \%$ & 35 & 32 & Yes \\
\hline HIV case 3 (SG) & 47.8 & $14.1 \%$ & $29.5 \%$ & 128 & 90 & No \\
\hline AGB-non HIV $(n=61)$ & $43.4 \pm 6.2$ & $14 \% \pm 8 \%$ & $34 \% \pm 22 \%$ & $60.6 \pm 18.1$ & $58.2 \pm 13.5$ & $5 \%$ \\
\hline SG-non HIV $(n=56)$ & $49.6 \pm 10.7$ & $22 \% \pm 9 \%$ & $42 \% \pm 20 \%$ & $59.5 \pm 18.5$ & $54.4 \pm 18.1$ & $27 \%$ \\
\hline
\end{tabular}

$A G B$ adjustable gastric band, $B M I$ body mass index, EWL excessive weight loss, HbA1c glycated hemoglobin, HIV human immunodeficiency virus, SG sleeve gastrectomy, T2DM type 2 diabetes mellitus, $T W L$ total weight loss. ${ }^{1}$ according to American Diabetes Association criteria [8]. Data in non-HIV group were described as mean \pm standard deviation 
reported are improvements in cardiovascular risk profile, obesity-related complications, and all-cause mortality $[2,7]$. Despite this, bariatric surgery remains an underutilized tool and data are limited for the HIV-infected population. Although reports [11, 12] have suggested that bariatric surgery is safe, there is a paucity of data describing the outcomes of T2DM in these individuals or, in fact, the uptake of surgery.

Summarized clinical outcomes for our case series ( $n$ =3) are presented alongside outcomes for patients with T2DM who were not HIV infected $(n=117)$ in Table 4. Case 1 (AGB) achieved weight loss, which was $53 \%$ excessive weight loss (EWL) in excess of the figure typically quoted for this procedure (40\%) [13]. This is particularly impressive as a restrictive procedure. Cases 1 and 2 were also noted to achieve greater \% EWL compared to the non-HIV group for their respective procedures. Case 3, however, achieved below average \% EWL for SG (30\% compared to $60 \%$ reported [14]), although this was not far from the average \% EWL for the non-HIV group $(42 \% \pm 20 \%)$. We speculate that several patient factors, including negative eating habits, depression, and sedentary life style, may all have contributed to this outcome.

In terms of T2DM, although only Case 2 achieved remission according to ADA criteria [8], it is notable that all cases achieved an improvement in HbA1c postoperatively. Ongoing monitoring for relapse is advisable. Case 1 would also have achieved remission were it not for the continuation of metformin postoperatively. Although T2DM outcomes for Case 3 did not objectively seem as successful, it is notable that individual insulin requirements and pill burden were reduced. Lack of remission was perhaps predictable given the longevity of T2DM and preoperative insulin dosage.

In all three cases, HIV status was not affected by bariatric surgery, which is consistent with existing literature $[4,6,11,12,15]$. There is a theoretical concern over drug absorption following bariatric surgery. One study to date has reported that, despite a mild reduction, drug levels following SG remained within the therapeutic range [12]. In our case series, the HIV status was not adversely affected by bariatric surgery.

\section{Conclusions}

In conclusion, our case series further supports the use of bariatric surgery as a safe treatment modality in individuals who are HIV positive [11]. Importantly, we have demonstrated the positive effect of bariatric surgery on T2DM in this group of patients. Further work would be beneficial to consolidate these findings.

\section{Abbreviations}

ADA: American Diabetes Association; AGB: Adjustable gastric banding; BMI: Body mass index; EWL: Excessive weight loss; GLP-1: Glucagon-like peptide-1; HAART: Highly active antiretroviral treatment; HbA1c: Glycated hemoglobin; HIV: Human immunodeficiency virus; MDT: Multidisciplinary team; NICE: National Institute for Health and Care Excellence; RYGB: Roux-enY gastric bypass; SG: Sleeve gastrectomy; SGLT-2: Sodium-glucose cotransporter-2; T2DM: Type 2 diabetes mellitus

\section{Acknowledgements}

The authors would like to thank the anonymized participants as well as the reviewers for their valuable suggestions.

\section{Funding}

No sources of funding declared.

\section{Availability of data and materials}

The datasets used and/or analyzed for the current study will be available on https://doi.org/10.3886/E104725V1 from July 2019 or contact the

corresponding author on reasonable request.

\section{Authors' contributions}

$W Y$ and $A Z$ were responsible for the acquisition, analysis, and interpretation of the data. GB, JS, and EE performed the bariatric operation and contributed to the data interpretation. MN, KS, and VG contributed to the conception and design of the study. WY, AZ, and VG were major contributors in writing the manuscript. All authors read and approved the final manuscript.

Ethics approval and consent to participate

Not applicable.

\section{Consent for publication}

Written informed consent was obtained from the patients for publication of this case report and any accompanying images. A copy of the written consent is available for review by the Editor-in-Chief of this journal.

\section{Competing interests}

The authors declare that they have no competing interests.

\section{Publisher's Note}

Springer Nature remains neutral with regard to jurisdictional claims in published maps and institutional affiliations.

\section{Author details}

'Bariatric Medicine, Chelsea and Westminster Hospital, 369 Fulham Road, Chelsea, London SW10 9NH, UK. ²Diabetes and Endocrinology, Diabetes and Metabolism, Chelsea and Westminster Hospital, 369 Fulham Road, Chelsea, London SW10 9NH, UK. ${ }^{3}$ HIV Medicine, Chelsea and Westminster Hospital, 369 Fulham Road, Chelsea, London SW10 9NH, UK. ${ }^{4}$ Bariatric Surgery, Chelsea and Westminster Hospital, 369 Fulham Road, Chelsea, London SW10 9NH, UK. ${ }^{5}$ Endocrine and Thyroid Surgery, Chelsea and Westminster Hospital, 369 Fulham Road, Chelsea, London SW10 9NH, UK. ${ }^{6}$ Endocrinology and Bariatric Medicine, Chelsea and Westminster Hospital, 369 Fulham Road, Chelsea, London SW10 9NH, UK. ${ }^{7}$ Beta Cell Diabetes Centre, Chelsea and Westminster Hospital, 369 Fulham Road, Chelsea, London SW10 9NH, UK.

Received: 15 November 2018 Accepted: 10 April 2019

Published online: 10 May 2019

\section{References}

1. Galli L, Salpietro S, Pellicciotta G, Galliani A, Piatti P, Hasson H, et al. Risk of type 2 diabetes among HIV-infected and healthy subjects in Italy. Eur J Epidemiol. 2012;27(8):657-65. https://doi.org/10.1007/s10654-012-9707-5. Epub 2012/06/23. PubMed PMID: 22722952

2. Mingrone G, Panunzi S, De Gaetano A, Guidone C, laconelli A, Leccesi L, et al. Bariatric surgery versus conventional medical therapy for type 2 diabetes. N Engl J Med. 2012;366(17):1577-85. https://doi.org/10.1056/ NEJMoa1200111. Epub 2012/03/28. PubMed PMID: 22449317

3. Razonable R, Estes L, Thompson G, et al. Gastric bypass surgery and serum concentrations of zidovudine, lamivudine, and nelfinavir [Abstract no. 
B10386]. Barcelona: Program and abstracts of the XIV International AIDS Conference; 2002

4. Flancbaum L, Drake V, Colarusso T, Belsley S. Initial experience with bariatric surgery in asymptomatic human immunodeficiency virus-infected patients. Surg Obes Relat Dis. 2005;1 (2):73-6. https://doi.org/10.1016/j.soard.2005.02. 004. Epub 2006/08/24. PubMed PMID: 16925217

5. Alfa-Wali M, Seechurn S, Ayodeji O, Nelson M, Shariq O, Milella M, et al. Outcomes of bariatric surgery in human immunodeficiency virus positive individuals: a single center experience. Minerva Chir. 2016;71(4):233-8. Epub 2016/01/20. PubMed PMID: 26785127

6. Eddy F, Elvin S, Sanmani L. Bariatric surgery: An HIV-positive patient's successful journey. Int J STD AIDS. 2016;27(1):70-1. https://doi.org/10.1177/ 0956462415571971. Epub 2015/02/11. PubMed PMID: 25663245

7. Schauer PR, Bhatt DL, Kirwan JP, Wolski K, Aminian A, Brethauer SA, et al. Bariatric Surgery versus Intensive Medical Therapy for Diabetes - 5-Year Outcomes. N Engl J Med. 2017;376(7):641-51. https://doi.org/10.1056/ NEJMoa1600869. PubMed PMID: 28199805

8. Buse JB, Caprio S, Cefalu WT, Ceriello A, Del Prato S, Inzucchi SE, et al. How Do We Define Cure of Diabetes? Diabetes Care. 2009;32(11):2133-5. https:// doi.org/10.2337/dc09-9036. PubMed PMID: PMC2768219

9. Samarasinghe $Y$, Mclntosh C, Feher MD. Diabetes and HIV: the role of a specialist clinic. Pract Diabetes Int. 2005;22(4):131-7. https://doi.org/10.1002/pdi.783.

10. Courcoulas AP, Goodpaster BH, Eagleton JK, Belle SH, Kalarchian MA, Lang W, et al. Surgical vs medical treatments for type 2 diabetes mellitus: a randomized clinical trial. JAMA Surg. 2014;149(7):707-15. https://doi.org/10 1001/jamasurg.2014.467. Epub 2014/06/06. PubMed PMID: 24899268; PubMed Central PMCID: PMCPMC4106661

11. Kassir R, Huart E, Tiffet O, Fresard A, Lucht F, Gagneux-Brunon A, et al. Feasibility of Bariatric Surgery in the HIV-Infected Patients. Obes Surg. 2017; 27(3):818-9. https://doi.org/10.1007/s11695-016-2538-9. Epub 2017/01/06. PubMed PMID: 28054292

12. Fysekidis M, Cohen R, Bekheit M, Chebib J, Boussairi A, Bihan H, et al. Sleeve gastrectomy is a safe and efficient procedure in HIV patients with morbid obesity: a case series with results in weight loss, comorbidity evolution, CD4 count, and viral load. Obes Surg. 2015;25(2):229-33. https://doi.org/10.1007/ s11695-014-1350-7. Epub 2014/06/28. PubMed PMID: 24968746

13. Wang X, C-z Z, X-s C, Zhao X, Yin K. Laparoscopic adjustable gastric banding: a report of 228 cases. Gastroenterol Rep. 2013;1(2):144-8. https:// doi.org/10.1093/gastro/got023. PubMed PMID: PMC3938002

14. Fischer L, Hildebrandt C, Bruckner T, Kenngott H, Linke GR, Gehrig T, et al. Excessive weight loss after sleeve gastrectomy: a systematic review. Obes Surg. 2012;22(5):721-31. https://doi.org/10.1007/s11695-012-0616-1. Epub 2012/03/14. PubMed PMID: 22411568

15. Fazylov R, Soto E, Merola S. Laparoscopic gastric bypass surgery in human immunodeficiency virus-infected patients. Surg Obes Relat Dis. 2007;3(6): 637-9. https://doi.org/10.1016/.soard.2007.08.012. Epub 2007/10/16 PubMed PMID: 17936082

Ready to submit your research? Choose BMC and benefit from:

- fast, convenient online submission

- thorough peer review by experienced researchers in your field

- rapid publication on acceptance

- support for research data, including large and complex data types

- gold Open Access which fosters wider collaboration and increased citations

- maximum visibility for your research: over $100 \mathrm{M}$ website views per year

At $\mathrm{BMC}$, research is always in progress.

Learn more biomedcentral.com/submissions 